\title{
Analisis Perilaku Kecurangan Akademik Siswa dalam Pelaksanaan Ujian di Sekolah
}

\author{
Zayyinul Mushthofa*, Ani Rusilowati, Sulhadi, \\ Putut Marwoto, Budi Naini Mindiyarto \\ Pendidikan Fisika S2, Program Pascasarjana, Universitas Negeri Semarang \\ *Corresponding Author. Email: zainsmart34@students.unnes.ac.id
}

\begin{abstract}
This study aims to describe the popular types of academic dishonesty, teachers' supervision, and the factors which motivate students to cheat. This research used the descriptive quantitative method with 260 students as respondents from 4 schools. Questionnaires were given online to the students. The data analysis technique used statistic descriptive. The result showed that the popular types of academic dishonesty among the students were asking their friends, carrying small notes, searching the answer on the web via cell phones, carrying textbooks, and etcetera. The teachers' or supervisors' supervision was good, but there were times when they were careless so that the students used the opportunity to cheat. During online examination supervision, the students stated that there was no particular supervision; therefore they took the advantage of this opportunity. The driving factors which caused the students to cheat were they considered the questions were too difficult; they did not have confidence in their own answers or abilities; they did not study; they had an opportunity to cheat; they wanted good grades, and they had some unanswered questions but the time was almost over.
\end{abstract}

\begin{abstract}
Abstrak: Penelitian ini bertujuan mendeskripsikan bentuk-bentuk kecurangan akademik yang sering dilakukan, bentuk pengawasan guru, dan faktor-faktor yang menyebabkan siswa melakukan hal tersebut. Metode penelitian yang digunakan adalah deskriptif kuantitatif dengan responden berjumlah 260 siswa yang berasal dari 4 sekolah. Instrumen yang digunakan adalah Quistioner yang diberikan secara online kepada siswa. Teknik analisis data menggunakan statistik deskriptif. Hasil penelitian menunjukkan bentuk-bentuk kecurangan akademik yang sering dilakukan adalah bertanya teman, membawa catatan kecil, membuka internet dari HP, membawa buku, dan bentuk lainnya. Pengawasan yang dilakukan guru/pengawas sudah baik namun tetap saja ada waktu dimana mereka lengah sehingga dimanfaatkan siswa melakukan kecurangan. Pada pengawasan ujian saat pembelajaran jarak jauh siswa menyatakan tidak ada pengawasan khusus sehingga banyak siswa yang memanfaatkan kesempatan ini. Faktor-faktor yang mendorong siswa melakukan kecurangan akademik saat ujian adalah: soal ujian yang diberikan dirasa sulit; kurang percaya dengan jawaban atau kemampuan sendiri; kurang belajar; males belajar; ada kesempatan menyontek; ingin mendapatkan nilai yang bagus; dan sebagian siswa menjawab terpaksa menyontek karena waktu ujian hampir selesai namun masih ada sebagian soal yang belum dijawab.
\end{abstract}

Article History

Received: $30-12-2020$

Revised: 11-03-2021

Accepted: 21-04-2021

Published: 07-06-2021

\section{Key Words:}

Academic Cheating, School, Exams.

\section{Sejarah Artikel}

Diterima: 30-12-2020

Direvisi: 11-03-2021

Disetujui: 21-04-2021

Diterbitkan: 07-06-2021

\section{Kata Kunci:}

Kecurangan Akademik, Sekolah, Ujian.

How to Cite: Mushthofa, Z., Rusilowati, A., Sulhadi, S., Marwoto, P., \& Mindiyarto, B. (2021). Analisis Perilaku Kecurangan Akademik Siswa dalam Pelaksanaan Ujian di Sekolah. Jurnal Kependidikan: Jurnal Hasil Penelitian dan Kajian Kepustakaan di Bidang Pendidikan, Pengajaran dan Pembelajaran, 7(2), 446-452. doi:https://doi.org/10.33394/jk.v7i2.3302

https://doi.org/10.33394/jk.v7i2.3302

This is an open-access article under the CC-BY-SA License.

\section{Pendahuluan}

Ujian atau penilaian merupakan salah satu bentuk evaluasi pembelajaran baik berfungsi formatif maupun sumatif. Hasil dari evaluasi pembelajaran ini diharapkan mampu memberikan gambaran kompetensi yang telah dimiliki oleh siswa. Pelaksanaan ujian yang 
efektif adalah siswa mengerjakan ujian dengan kemampuannya sendiri. Namun realitanya masih ada sebagian siswa yang melakukan kecurangan saat melaksanakan ujian. Penelitian dari Khodaie, et al. (2011) sebanyak 95\% dari 336 siswa di sekolah Tehran mengaku pernah mencontek saat ujian.

Kecurangan akademik merupakan perbuatan yang tidak dibenarkan untuk mendapatkan prestasi akademik yang baik. Kecurangan akademik muncul akibat beberapa faktor. Faktor-faktor pendorong perbuatan tersebut antara lain 10\% dipengaruhi oleh kontrol diri, efikasi diri akademik, dan prestasi akademik dan 90\% lainnya dipengaruhi oleh tingkat hukuman yang diberikan atas perilaku tersebut, pengaruh teman sebaya, persepsi terhadap materi dan pengajar serta faktor lainnya (Aulia, 2015). Hal ini dapat dikatakan faktor eksternal justru berpengaruh besar dalam melakukan kecurangan akademik.

Tuntutan nilai ujian yang harus memenuhi Kriteria Ketuntasan Minimal (KKM) menjadikan sebagian siswa melakukan hal-hal yang tidak dibenarkan. Siswa dalam kategori menengah ke atas menyatakan terpaksa melakukan kecurangan untuk mencitrakan kemajuan dalam akademik yang diperolehnya (Galloway, 2012). Kecurangan akademik juga dilakukan demi mendapatkan nilai yang maksimal agar berpeluang besar untuk mendapatkan pekerjaan yang mereka impikan (Högberg, 2011).

Penelitian yang dilakukan oleh Nursalam, et al. (2016) menjelaskan bahwa bentukbentuk kecurangan akademik berupa menyontek pekerjaan teman pada saat ujian, menyalin tugas teman, membuka internet melalui handphone, membuka buku saat ujian, dan copy paste dari internet. Kecurangan ini dapat terjadi dikarenakan tingkat pengawasan ujian yang lemah (Fransiska \& Utami, 2019). Perbuatan-perbuatan tersebut perlu diminimalisir bahkan dihilangkan dalam dunia akademik seperti sekolah.

Satuan Pendidikan (Sekolah), guru, dan orang tua memiliki peran penting dalam mengatasi kecurangan akademik yang dilakukan siswa. Menurut Sagoro (2013) kecurangan akademik dapat diatasi jika terdapat sinergi antara siswa, guru, dan lembaga. Guru yang memiliki kemampuan kepemimpinan, saling bekerja sama, dan etos kerja yang tinggi ternyata memiliki tingkat kecurangan akademik yang rendah diantara siswanya (Ramberg \& Modin, 2019). Budaya penguasaan materi/kompetensi harus ditingkatkan dengan menjunjung tinggi tujuan pendidikan menjadi prioritas maka peluang melakukan kecurangan akademik lebih kecil dibandingkan budaya yang menjadikan nilai ujian sebagai prioritas (Day et al., 2011).

Berdasarkan uraian di atas, penelitian ini bertujuan untuk mendeskripsikan bentukbentuk kecurangan akademik yang sering dilakukan oleh siswa, pengawasan ujian yang dilakukan oleh guru, dan faktor-faktor yang mempengaruhi siswa melakukan perbuatan tersebut. Penelitian ini berfokus pada tingkat SMA. Hal ini karena siswa pada usia transisi pendidikan menengah menuju perguruan tinggi memiliki kecenderungan melakukan kecurangan akademik (Clariana et al., 2012).

\section{Metode Penelitian}

Penelitian ini menggunakan metode kuantitatif dengan desain deskriptif eksploratif. Sampel yang digunakan dalam penelitian ini berjumlah 260 siswa yang berasal dari SMAN A di Cilacap, SMA Islam B di Semarang, SMA C di Semarang, dan MA D di Jepara. Responden terdiri dari 110 siswa dan 150 siswi dengan jurusan MIPA sebanyak 177 dan IPS sebanyak 83. Dari 260 terdapat 137 kelas X, 77 kelas XI, dan 46 kelas XII. Teknik sampling yang digunakan adalah proportional random sampling. Pengumpulan data dilakukan dengan cara menyebarkan quistioner tentang bentuk-bentuk kecurangan akademik yang sering dilakukan, bentuk pengawasan guru, dan faktor-faktor yang mendorong siswa dalam 
melakukan kecurangan akademik. Teknik analisis data menggunakan statistik deskriptif. Data ditampilkan dalam bentuk grafik kemudian dijelaskan secara deskripsif.

\section{Hasil Penelitian dan Pembahasan}

Penelitian dimulai dengan menyiapkan quistioner secara online kemudian diberikan kepada responden untuk diisi. Hasil penelitian dalam mengungkap kecurangan akademik siswa saat ujian lebih difokuskan pada kegiatan menyontek. Menyontek adalah perilaku kecurangan akademik yang paling sering dilakukan saat ujian berlangsung. Persentase siswa yang pernah menyontek atau melakukan kecurangan akademik dapat dilihat pada Gambar 1 dibawah ini.

\section{Perilaku Menyontek}

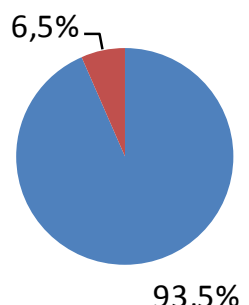

- Pernah

Tidak Pernah

$93,5 \%$

Gambar 1. Presentase Siswa dalam Menyontek

Berdasarkan Gambar 1, terdapat 93,5\% dari 260 siswa mengaku pernah melakukan kecurangan akademik saat mengerjakan ujian selama SMA. Hanya ada 14 siswa atau 6,5\% yang mengaku tidak pernah menyontek saat ujian di SMA. Sedangkan jumlah siswa terhadap frekuensi menyontek atau kecurangan akademik dinyatakan dalam Gambar 2.

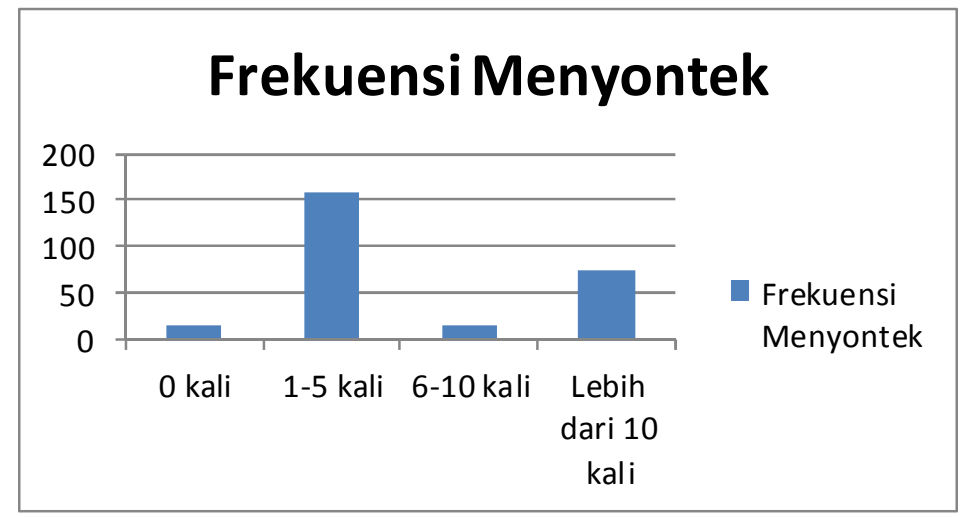

Gambar 2. Frekuensi Siswa dalam Menyontek

Pada Gambar 2, dari 93,5\% siswa yang pernah menyontek terdapat 158 siswa melakukan kecurangan akademik sebanyak 1-5 kali. Pada urutan kedua terdapat 74 siswa mengaku melakukannya sebanyak lebih dari 10 kali, 14 siswa melakukannya sebanyak 6-10 kali dan sisanya mengaku tidak pernah menyontek saat ujian. Sebagian siswa ketahuan oleh guru/pengawas saat menyontek. Berikut frekuensi siswa ketahuan menyontek oleh guru/pengawas dapat dilihat pada Gambar 3. 


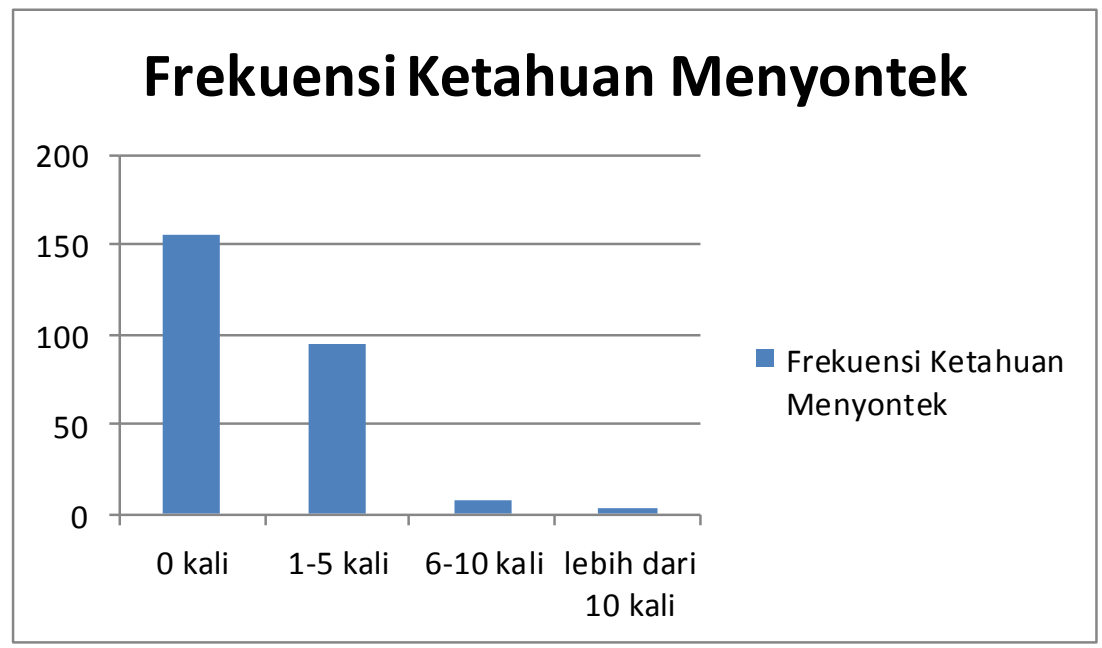

Gambar 3. Frekuensi Ketahuan Menyontek

Berdasarkan Gambar 3, dari total 246 siswa yang pernah menyontek terdapat 155 siswa tidak pernah ketahuan curang saat ujian. Pada kasus siswa yang ketahuan menyontek, terdapat 94 siswa ketahuan menyontek sebanyak 1-5 kali, 8 siswa ketahuan menyontek 6-10 kali, dan 3 siswa ketahuan menyontek lebih dari 10 kali. Hal ini dapat disimpulkan pengawasan ujian masih terdapat kesempatan besar siswa melakukan kecurangan akademik. Adapun bentuk-bentuk kecurangan akademik yang sering dilakukan siswa saat ujian dapat dilihat pada Gambar 4.

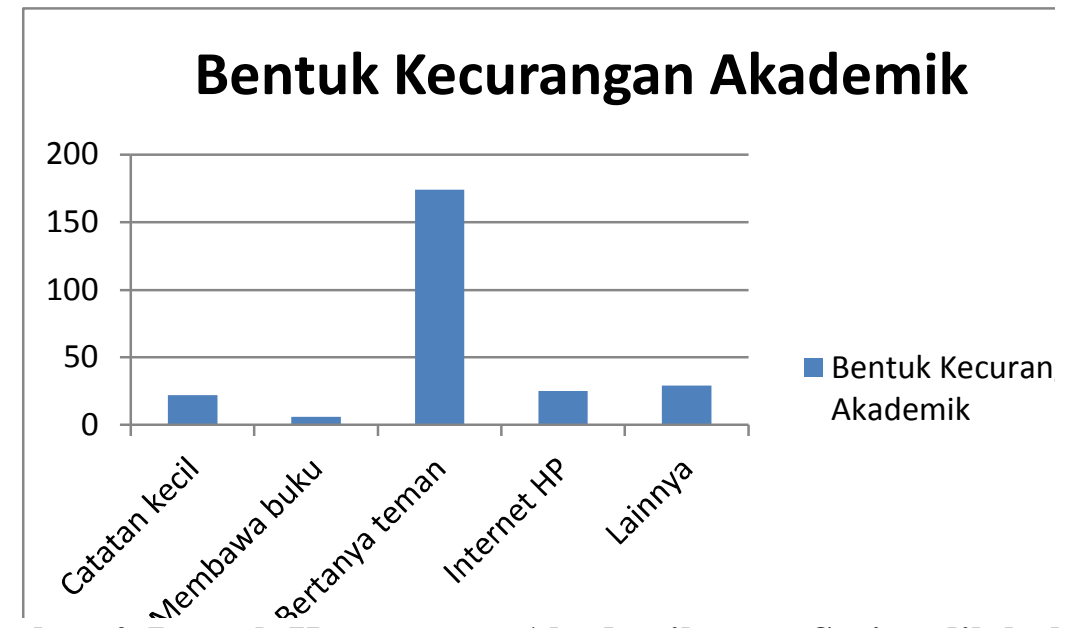

Gambar 4. Bentuk Kecurangan Akademik yang Sering dilakukan

Pada Gambar 4 diatas, sebanyak 22 siswa mengaku sering membawa catatan kecil saat ujian, 6 siswa membawa buku, 174 siswa bertanya jawaban pada teman, 25 siswa membuka internet di HP mereka, dan 29 siswa melakukan kecurangan akademik dalam bentuk lain. Bentuk kecurangan akademik yang paling sering dilakukan siswa saat ujian adalah bertanya pada teman. Bentuk kecurangan ini dapat dilakukan tanpa melakukan persiapan sebelumnya. Berbeda dengan bentuk kecurangan seperti membuat catatan kecil, membawa buku, membawa HP untuk mengakses internet perlu adanya persiapan yang dilakukan siswa sebelum mengerjakan ujian. Pada bentuk kecurangan lain siswa mempunyai strategi dalam membuat kode jawaban yang digunakan bersama dengan siswa lain yang sama-sama melakukan kecurangan akademik. Abdullahi \& Mansor (2017) menyatakan kecurangan terjadi karena pelaku memiliki kemampuan untuk melakukannya. Hasil penelitian Artani \& Wetra (2017) terdapat pengaruh positif kemampuan terhadap terjadinya 
kecurangan akademik. Budaya kecurangan akademik ini membuat generasi selanjutnya juga akan melakukan hal yang sama jika tidak ada upaya dalam menghentikannya. Menurut Ip, et al. (2016) menyontek terjadi karena adanya budaya menyontek yang dilakukan di sekolah tersebut.

Sebagian besar siswa mengaku guru/pengawas ujian sudah baik dalam mengawasi ujian saat pembelajaran tatap muka. Hanya saja tetap ada waktu dimana guru/pengawas lengah dalam mengawasi sehingga kesempatan ini dimanfaatkan siswa untuk melakukan kecurangan akademik. Berbeda dengan pembelajaran jarak jauh, siswa menyatakan tidak ada pengawasan khusus saat pelakasanaan ujian. Siswa dapat memanfaatkan teknologi dalam mencari jawaban dan dapat menggunakan teknologi informasi dan komunikasi dalam bertukar jawaban. Pada pelaksanaan ujian sebagian guru hanya mengingatkan untuk bersikap jujur dalam mengerjakan ujian. Namun, karena keterbatasan kondisi kurang memungkinkan untuk melakukan pengawasan secara maksimal.

Hasil dari quistioner yang telah diberikan kepada siswa bahwa faktor-faktor yang mendorong mereka melakukan kecurangan akademik saat ujian adalah soal ujian yang diberikan dirasa sulit, kurang percaya dengan jawaban atau kemampuan sendiri, kurang belajar, malas belajar, ada kesempatan menyontek, ingin mendapatkan nilai yang bagus, dan sebagian siswa menjawab terpaksa menyontek karena waktu ujian hampir selesai namun masih ada sebagian soal yang belum dijawab. Perubahan kurikulum 2013 revisi 2016 yang mengharuskan soal ujian berbasis high older thinking skills (HOTS) menjadikan sebagian siswa merasakan perubahan soal ujian yang semakin susah. Efikasi diri atau kepercayaan terhadap kemampuan pribadi yang rendah menjadi faktor yang paling berpengaruh melakukan kecurangan akademik (Purnamasari, 2013). Menurut Suryani, et al (2020) efikasi diri yang tinggi akan memberikan dampak positif terhadap hasil belajar. Ketika faktor situasional seperti adanya kesempatan bertemu dengan faktor individu misalnya ingin mendapat nilai bagus namun malas belajar, hal ini akan meningkatkan peluang individu untuk melakukan kecurangan akademik (Pramadi et al., 2017).

\section{Kesimpulan}

Kesimpulan yang diperoleh dari hasil penelitian ini antara lain adalah 93,5\% siswa mengaku pernah menyontek selama belajar di SMA. Sebagian besar siswa melakukannya sebanyak 1-5 kali dan tidak ketahuan oleh guru/pengawas ujian. Bentuk-bentuk kecurangan akademik yang sering dilakukan adalah bertanya teman menjadi kecurangan yang paling sering dilakukan. Kecurangan akademik lain yang juga dilakukan siswa adalah membuat catatan kecil, membuka internet menggunakan HP, membawa buku. Pengawasan yang dilakukan guru/pengawas sudah baik namun tetap saja ada waktu dimana mereka lengah sehingga dimanfaatkan siswa melakukan kecurangan. Pada pengawasan ujian saat pembelajaran jarak jauh siswa menyatakan tidak ada pengawasan khusus sehingga banyak siswa yang memanfaatkan kesempatan ini. Faktor-faktor yang mendorong mereka melakukan kecurangan akademik saat ujian adalah soal ujian yang diberikan dirasa sulit, kurang percaya dengan jawaban atau kemampuan sendiri, kurang belajar, malas belajar, ada kesempatan menyontek, ingin mendapatkan nilai yang bagus, dan sebagian siswa menjawab terpaksa menyontek karena waktu ujian hampir selesai namun masih ada sebagian soal yang belum dijawab.

\section{Saran}

Berdasarkan hasil penelitian yang telah dilakukan, sekolah dapat menanamkan pendidikan karakter berupa sikap jujur dan rajin belajar serta memberikan bimbingan belajar kepada 
siswa yang merasa kesulitan untuk mencegah terjadinya kecurangan akademik saat ujian. Teknis pengawasan ujian juga bisa dikembangkan dengan penggunaan teknologi seperti CCTV untuk merekam tindakan siswa selama mengerjakan ujian.

\section{Daftar Pustaka}

Abdullahi, R., \& Mansor, N. (2017). Fraud Triangle Theory and Fraud Diamond Theory . Understanding the Fraud Triangle Theory and Fraud Diamond Theory . Understanding the Convergent and Divergent For Future Research. International Journal of Academic Research in Accounting, Finance and Management Sciences, 5(October 2015), 38-45. https://doi.org/10.6007/IJARAFMS/v5-3/1823

Artani, K. T. B., \& Wetra, I. W. (2017). Pengaruh Academic Self Efficacy Dan Fraud Diamond Terhadap Perilaku Kecurangan Akademik Mahasiswa Akuntansi Di Bali. Jurnal Riset Akuntansi, 7(2), 123-132. http://jurnal.unmas.ac.id/index.php/JUARA/article

Aulia, F. (2015). Faktor-Faktor yang Terkait dengan Kecurangan Akademik pada Mahasiswa. $\begin{array}{lllll}\text { Jurnal } & \text { RAP } & \text { 6(1), } & \text { 23-32. }\end{array}$ http://ejournal.unp.ac.id/index.php/psikologi/article/view/6647

Clariana, M., Gotzens, C., del Mar, M., \& Cladellas, R. (2012). Procrastination and cheating from secondary school to university/Procrastinacion y engaño académico desde la secundaria hasta la universidad. Electronic Journal of Research in Educational $\begin{array}{lll}\text { Psychology, } & \text { 10(2), 737+. }\end{array}$ http://tp5jv5du8m.search.serialssolutions.com.etechconricyt.idm.oclc.org/?ctx_ver=Z 39.88-2004\&ctx_enc=info\%3Aofi\%2Fenc\%3AUTF-

8\&rfr_id=info\%3Asid\%2Fsummon.serialssolutions.com\&rft_val_fmt=info\%3Aofi\% 2Ffmt\%3Akev\%3Amtx\%3Ajournal\&rft.genre=article\&rft.atitle $=$

Day, N. E., Hudson, D., Dobies, P. R., \& Waris, R. (2011). Student or situation? Personality and classroom context as predictors of attitudes about business school cheating. Social Psychology of Education, 14(2), 261-282. https://doi.org/10.1007/s11218-010-9145-8

Fransiska, I. S., \& Utami, H. (2019). Perilaku Kecurangan Akademik Mahasiswa: Perspektif Fraud Diamond Theory. Jurnal Akuntansi Aktual, 6(2), 316-323. https://doi.org/10.17977/um004v6i22019p316

Galloway, M. K. (2012). Cheating in Advantaged High Schools: Prevalence, Justifications, and Possibilities for Change. Ethics and Behavior, 22(5), 378-399. https://doi.org/10.1080/10508422.2012.679143

Högberg, R. (2011). Cheating as subversive and strategic resistance: Vocational students' resistance and conformity towards academic subjects in a Swedish upper secondary school. Ethnography and Education, 6(3), 341-355. https://doi.org/10.1080/17457823.2011.610584

Ip, E. J., Nguyen, K., Shah, B. M., Doroudgar, S., \& Bidwal, M. K. (2016). Motivations and predictors of cheating in pharmacy school. American Journal of Pharmaceutical Education, 80(8). https://doi.org/10.5688/ajpe808133

Khodaie, E., Moghadamzadeh, A., \& Salehi, K. (2011). Factors affecting the probability of academic cheating school students in Tehran. Procedia - Social and Behavioral Sciences, 29, 1587-1595. https://doi.org/10.1016/j.sbspro.2011.11.401

Nursalam, N., Bani, S., \& Munirah, M. (2016). Bentuk Kecurangan Akademik (Academic Cheating) Mahasiswa Pgmi Fakultas Tarbiyah Dan Keguruan Uin Alauddin Makassar. Lentera Pendidikan: Jurnal Ilmu Tarbiyah Dan Keguruan, 16(2), 127138. https://doi.org/10.24252/lp.2013v16n2a1

Jurnal Kependidikan Vol. 7. No. 2 : Juni 2021 
Pramadi, A., Pali, M., Hanurawan, F., \& Atmoko, A. (2017). Academic Cheating in School: A Process of Dissonance Between Knowledge and Conduct. Mediterranean Journal of Social Sciences, 8(6), 155-162. https://doi.org/10.1515/mjss-2017-0052

Purnamasari, D. (2013). Faktor-faktor yang mempengaruhi kecurangan akademik pada mahasiswa. Educational Psychology Journal, 2(1), 13-21. file:///D:/My Documents/Downloads/2581-Article Text-5082-1-10-20131203.pdf

Ramberg, J., \& Modin, B. (2019). School effectiveness and student cheating: Do students' grades and moral standards matter for this relationship? Social Psychology of Education, 22(3), 517-538. https://doi.org/10.1007/s11218-019-09486-6

Sagoro, E. M. (2013). Pensinergian Mahasiswa, Dosen, Dan Lembaga Dalam Pencegahan Kecurangan Akademik Mahasiswa Akuntansi. Jurnal Pendidikan Akuntansi Indonesia, 11(2), 54-67. https://doi.org/10.21831/jpai.v11i2.1691

Suryani, L., Seto, S., \& Bantas, M. (2020). Hubungan Efikasi Diri dan Motivasi Belajar Terhadap Hasil Belajar Berbasis E-Learning pada Mahasiswa Program Studi Pendidikan Matematika Universitas Flores. Jurnal Kependidikan: Jurnal Hasil Penelitian dan Kajian Kepustakaan di Bidang Pendidikan, Pengajaran dan Pembelajaran, 6(2), 275-283. doi:https://doi.org/10.33394/jk.v6i2.2609 